\title{
Audit Quality and Stock Return Co-Movement: Evidence from Vietnam*
}

\author{
Chi Bich Thi PHAM', Thu Minh Thi VU², Linh Ha NGUYEN ${ }^{3}$, Dung Duc NGUYEN ${ }^{4}$
}

Received: April 30, 2020 Revised: May 10, 2020 Accepted: June 09, 2020

\begin{abstract}
This paper aims to explore the relationship between the quality of the audit and the level of stock return co-movement in the context of the Vietnamese emerging market. The empirical study is designed based on the quatitative method and deductive approach. The panel datasetincludes 256listed firmsfrom different industries, with 1115 firm-year observations on Ho Chi Minh City Stock Exchange for the period from 2014 to 2018. In the research, we built the econometric regression model, using stock return synchronicity and audit quality as the dependent and independent variable, respectively. Some control variables are also added to the econometric regression models as they are well-documented in prior research to have an effect on stock price synchronicity. To improve the accuracy of the regression coefficients, besidetheOrdinary Least Squares, we employ theRandom Effects Modeland theFixed Effects Model for better statistical analysis of panel data set. The resultsshow that the quality of the audit is positively correlated to stock price synchronicity. This finding suggests that stock returns of companies with higher quality of the audit are more synchronous with the market. Results for other control variables also support our reasoning for the main findings.
\end{abstract}

Keywords: Audit Quality, Stock Return Synchronicity, Informational Environment, Firm-Specific Information, Vietnam

JEL Classification Code:G12, M41, M42

\section{Introduction}

In the literature of accounting and finance,stock synchronicity is used in capital marketto represent the

*Acknowledgements:

This research is funded by the National Economics University (NEU), Hanoi, Vietnam. The authors thank anonymous referees for their contributions and the NEU for funding this research.

${ }^{1}$ First Author. Director of the Accounting and Finance Department, National Economics University, Vietnam. Email: chipbkt68@gmail.com

${ }^{2}$ Corresponding Author. Lecturer, School of Accounting and Auditing, National Economics University, Vietnam [Postal Address: 207

Giai Phong, Dong Tam, Hai Ba Trung, Hanoi, 113068, Vietnam] Tel: +84 848288886, Email: vuminhthu.neu@gmail.com

${ }_{3}$ Lecturer, School of Accounting and Auditing, National Economics University, Vietnam. Email: halinh1510@gmail.com

${ }^{4}$ Lecturer, School of Accounting and Auditing, National Economics University, Vietnam. Email: dungnd2141@gmail.com

(c) Copyright: The Author(s)

This is an Open Access article distributed under the terms of the Creative Commons Attribution Non-Commercial License (http://Creativecommons.org/licenses/by-nc/4.0/) which permits unrestricted noncommercial use, distribution, and reproduction in any medium, provided the original work is properly cited. movement of stock prices in the same direction with the market. This concept is often studied in relation to the quality of the market information. It implies different levels of market efficiency according to different contexts. In other words, stock price synchronicity can function differently in different markets.

Another strand of literature that is inextricably linked with the efficiency of the informational environment is audit quality. The concept "audit", derived from the Latin word meaning "to hear", emerged inthe 1840 s with the objective of verifying the true and fairness of information presented in corporate reports. Although auditing effectiveness can vary and depends on audit quality, it is well-documented in previous research that auditing is anuseful tool in limiting biased reporting, improving firm's perfomance,reducing agency problem, and information asymmetry (Kim, Chung, \& Firth, 2003; Rahman,Meah,\& Chaudhory, 2019).

In this study, we pull together theabove two concepts and propose that audit quality has a significant impact on the stock synchronicity in the case of the Vietnameseemerging market. After nearly two decades of development, the Vietnamese market has experienced rapid growth with 
two stock exchanges. Ho Chi MinhCity stock exchange is currently the larger one that surpasses the other in terms of listed companies, trading volume, as well as market capitalisation. Despite the achievement and potential prospect, it is undeniable that Vietnam's economy is still small and partially open, inwhich the stock market isfar short ofbeing perfect. Hence, it might be more interesting to investigate the association between the quality of the audit and stock return synchronicity in the context of Vietnamese emerging market, as stock price tracks its firm-specifics more loosely in a less transparent and more speculative market.

Our finding contributes to the small literature studying the relationship between these two factors. The research question is: "Doesa relationship between audit quality and stock price synchronicity exist?"Based on the research's objective, we adopt the deductive approach and quantitative research design to investigate the causal relationships between audit quality and stock return synchronicity. Accordingly, the article is structure around four sections, including theliterature review, methodology, result analysis, and the conclusion.

\section{Literature Review}

\subsection{Audit Quality}

The quality of the audit is the likelihood that the auditors will detect and report material misstatements in the client's accounting reports (DeAngelo, 1981). A combination offraudulent financial statements and a poor-quality audit might lead to seriouslyeconomic losses for users, or worse, to a crisis for the whole economy. The world will never forget the lesson it learned from the demise ofenergy company Enron andits audit firmArthur Andersen LLP. Therefore, it can be said that the auditor, as an insurance provider and information intermediary, have an essential role in verifying the accuracy and reliability of the firms' financial statements before they are published (Mansi, Maxwell,\& Miller, 2014).

Previous studies also paid much attention to the topic of audit quality and concurred in its positive impacts on various aspects. According to agency theory, it is considered to have a crucial role in mitigating agency conflict. Thereliable financial reporting guaranteed by the audit can enhance management accountability and be an effective tool for shareholders to monitor management tasks (Salehi, Moradi,\& Paiydarmanesh,2017).Market-wide, auditing plays a vital role in alleviating information asymmetry between insiders and outsidersby improving the quality of informationpresented in financial statements and reducing the earnings management (Almarayeh, Aibar-Guzmán, \& Abdullatif, 2020; Chae, Nakano, \& Fujitani,2020; Cohen, Dey,\&Lys, 2008). Hussainey (2009) found that investors are able to improve theirpredictions on firms' future performance and reduce risks and uncertaintywhen accounting reports are verified by a high-quality audit firmssuch as the Big Four accounting firms. A recent study by Legoria, Reichelt, and Soileau (2017)investigating the effect of audit quality on corporate disclosure revealed that the quality of the audit firms explains the client firms'choice to mandatorily disclose their major customers' identities. In summary, the benefit of assurance is recognised in protecting financial report users, including investors, and in enhancing the transparency and efficiency of the information environment.

\subsection{Stock Price Synchronicity}

Roll (1988) defined R-square from the traditional CAPM model. He posited that stock price variation is caused by different levels of variation, including firm-specific variation, industry-level variation, and market-level variation. The last two belong to systematic variation. The level of the synchronous movement depends on the proportion of systematic information incorporated in stock price, which is captured by the value of determination's coefficient (R-square) in the regression model. In other words, the higher level of stock return variation that can be explained by industry and market variation, the higher level of stock price synchronicity in the market. From the time of Roll's research, numerous and extensive works have been done on stock price synchronicityusing the value of R-squared estimated through regressingindividual stock return to the industry and market returns. However, the researchers' opinions on the concept of stock price synchronicity, which is often studied in association with the efficiency of the information environment, are not consistent.

On the one hand, theconventional wisdom is thatahigherlevel of stock synchronicity meansa smaller amount of firm-specific information capitalised in the share price, which is due to theinefficient or intransparent information environment and vice versa. Roll (1988) also supported this argument. He showed that stock return's co-movement depends on the proportion of firm-level and market-level information reflected into the price of shares. In detail, a low value of R-square seems to 'imply the existence of either private information or else occasional frenzy unrelated to concrete information' (1988, p.566).Motivated byRoll's research, a number of studies carried out mainly in developed markets withdifferent scales, from country to cross-country level, asserted the negative relationship between return synchronicity and the quality of information environment. These studies' findings suggested that there is a low level of stock price synchronicity in developed markets, which is due to their strong legal system, well-established institutional structure, and informed trading. Stocksin these markets are more informational with better price discovery.

There are two levels of the information environment, including market-level (e.g., property right protections 
and governmental regulations) and firm-level (e.g., corporate governance mechanism, corporate reporting, and disclosure). It is well established that both of these information environment's levels indeveloped markets are more efficient and transparent than those inemerging and developing markets (Chen \& Yuan, 2004; Hu \& Liu, 2013; Jin\& Myers, 2006). Accordingly, Morck, Yeung, and $\mathrm{Yu}(2000)$ proposed that a strong legal system for investor protection in developed markets encourages investors to conduct informed tradings, leading to a high level of firm's private information in stock price and, therefore, lower level of synchronicity. They examinedsynchronous movement of stock prices worldwide at the countrylevel and came to the conclusion that stock prices move together more in poor economies than in rich economies. FollowingMorck, Yeung, and Yu(2000), Jin and Myers (2006) observed crosscountry synchronicity and pointed out that some degree of opacity (lack of transparency) reduces the value of R-square. Likewise, Haggard,Martin, and Pereira (2008) argued that greater disclosure reveals more firm-private information and reduces the incidence of stock price crashes.

Further studies also used stock-price synchronicity as a reciprocal measure for firm-specific information, and added support to suchview (Fernandes \& Ferreira, 2009; Hutton, Marcus, \& Tehranian, 2009). At firm-level, theasynchronous movement of stock return with themarket's return is explained by the firm's inefficient governance mechanism. Typical firm characteristic of high concentrated ownership by family members or government in emerging markets enables them to withhold firm private information to outside investors and create opportunities for them to extract private control benefits at the expense of outside investors(Bertrand,Mehta, \& Mullainathan, 2002). Consequently, it is more expensive for outsiders to acquire firm fundamentals, discouraging them from making informed trading, and leading to less capitalization of firm-specific information in stock price or high synchronicity. Gul, Kim, and Qiu (2010) also concluded that synchronicity is a concave function of ownership by the largest shareholder and foreign ownership is inversely related to synchronicity as foreign shareholders may be more effective in monitoring firm's insiders and improving the agency problem.

On the other hand, a school of thoughts that recently becomes more dominant in emerging markets, interpreted the correlation betweenstock price synchronicity and the information environment in the contrasting way.There are reasons to support this claim. Firstly, Dasgupta, Gan, and Gao (2010) explained that, in a market with efficient information, stock price only responds to announcements or events that are new to the market and are not incorporated in the price. As the information environment surrounding the firm is improved, firm-specific information becomes available to all participants in the market. More firm's private information disclosed today should be associated with less firm's private information revealedin the future and, therefore, a high level of return synchronicity. Return synchronicity, as described by Dasgupta, Gan, and Gao (2010), has the dynamic behavior that will first decrease when new information is impounded in stock prices, but increase subsequently.

The second explanation for the positive relationship has something to do with the role of foreign investors in the market. International investors, especially institutional investors, are the most dynamic participants of the emerging market (Farooq \& Ahmed, 2014). They often come from developed countries with astrong informational environment and, hence, expect to experience the low level of information asymmetry in the market they invest. They will feel more confident to buy shares of companies with good corporate governance mechanism and avoid or try to minimise thefirmspecific information's risk. As a result, the price of stocks owned by international investors will capitalize moremarketwideinformation and, therefore, more synchronous asHu and Liu (2013)claimed:'we do find stocks with higher R-square are more likely to be widely held by institutional investors than those with lower R-square' (2013, p.20).Lastly, the literature suggested that large firms with efficient corporate governance in the emerging market often reveal more macro-economic information and have more synchronize trading with themarket(Piotroski \& Roulston, 2004; Chan \& Hameed, 2006). Accordingly, various studiesusedstock price synchronicity asthe direct proxy for information environment quality or stock price informationtoobserve market behaviors that jointly validate their interpretations of the stock price's synchronous movement (Anh, Thu, \& Quynh, 2020; Farooq \& Ahmed, 2014; Vo, 2017).

\subsection{The Relationship between Audit Quality and Stock Price Synchronicity}

Despite a large body of literature studying stock price synchronicity, very little researchfocuseson its relationship with audit quality. As our literature review shows, both of them are inextricably linked to the concept of information environment. However, while the positive effect of audit quality on information environment is agreed amongresearchers, mixed results found on the relationship between synchronicity and information environment. Stock return synchronicity behaves differently in different type or market and econony. Hence, it is not a surprise if there exist different viewpoints on the association between audit quality and stock price co-movement. Gul, Kim, and Qiu (2010) reported that it is anantagonistic relationship as a high-quality audit helps to reveal more reliable and greater firm-specific information to the public and, thus, makes the stock prices less synchronous. He also stated in his study that firms with low return co-movement are more likely to 
choose high-quality auditors (Big Four auditors). However, the relationship between audit quality and stock price synchronicity can be interpreted the other way around if it comes to the second viewpoint about synchronicity in the emerging market.Our hypothesis is illustrated by Figure 1.

Hypothesis: There exist a significant relationship between stock return synchronicity and audit quality

\section{Research Methodology}

\subsection{Research Methods}

\subsubsection{Research Model}

We conduct a quantitative research, which employs the deductive approach to investigate the relationship between the audit quality and stock price synchronicity in the context of the emerging market in Vietnam. To test the four hypotheses, we build the model shown in Equation1.

$$
\text { SYNCHit }=\beta 0+\beta 1 \text { AUDITit }+\gamma \text { CONTROLit }+\varepsilon i t
$$

Where:

SYNCHit is the stock price synchronicity of firm i at time $\mathrm{t}$, estimated by Equation 3 and Equation 4

AUDITit is the audit quality of firm $\mathrm{i}$ at time $\mathrm{t}$

CONTROLit represents for control variables of firm i at time $\mathrm{t}$

\subsubsection{Measure for Audit Quality (AUDIT)}

The literature uses multiple measures for the quality of the audit. A number of previous studies linked the audit quality to the size of the audit firm. The literature recognised audit firm size as a good audit quality's indication. Compared to smaller audit firms, big audit offices are expected to face less litigation in the future becausetheypossessa combination of competent, skilled specialists and the high technology capacity.Recent research also confirmed that the Big Four firms have higher audit quality than the others and that client companies' shareholders favor Big Four firms with hope of receivinganexcellentaudit performance (Wachid \& Yunita, 2019). We follow previous studies and employ the size of the audit firms to measure audit quality. AUDIT is the dummy variable, which receives the value of 1 if the audit firm is big four or the value of 0 otherwise.

\subsubsection{Measure for Stock Price Synchronicity (SYNCH)}

$$
F R i, j, t=\alpha i, 0+\alpha i, 1 M R t+\alpha i, 2 I R j, t+\varepsilon i, t
$$

Where:

$\mathrm{FR}_{\mathrm{i}, \mathrm{t}, \mathrm{t}}$ is the firm i's return in industry $\mathrm{j}$ at time $\mathrm{t}$

$\mathrm{MR}_{\mathrm{i}, \mathrm{t}, \mathrm{t}}$ is the market's return at time $\mathrm{t}$

$I_{\mathrm{j}, \mathrm{t}}$ is the industry $\mathrm{j}$ 's return at time $\mathrm{t}$

In the traditional model suggested by Roll (1988) (Equation 2 ), the individual firm return is regressed to the returns of the market and industry. The value of R-square (coefficient of determination) represents the extent to which the variation on the firm's stock return can be explained by the systematic variations, including market-wide and industry variation. The higher value of R-square means the higher level of stock price synchronicity. In contrast, a low level of R-square might imply the higher level of firm-specific information incorporated in stock price. Morck, Yeung, and Yu(2000) argued that, in an emerging market, the dominance of few industries over the others makes it difficult to distinguish their effects from the market's effect. Besides, the return of a industry might reflect firm-specific information of dominant firms in that industry rather than typical industry news. Accordingly, he proposed to remove industry return from Roll's traditional model, using only the return of the market (Equation 3). Finally, due to the natural limitation of R-square value, which is bounded within the range of $[0,1]$, the logarithmic transformation of $R^{2}(S Y N C H)$ is employed as the measure for stock price synchronicity (Equation 4).

$$
F R i, j, t=\alpha i, 0+\alpha i, 1 M R t+\varepsilon i, t
$$

Where:

$\mathrm{FR}_{\mathrm{i}, \mathrm{t}, \mathrm{t}}$ is the firm i's return in industry $\mathrm{j}$ at day $\mathrm{t}$

$\mathrm{MR}_{\mathrm{m}, \mathrm{t}}$ is the market's return at day $\mathrm{t}$

$$
S Y N C H i, t=\log [R 2 /(1-R 2)]
$$

\subsubsection{Control Variables (CONTROL)}

We also include some control variables as they are well documented in prior research to have an impact on stock price synchronicity.

Board independence, coded as INDEP, is measured by the number of non-executive members on the board. The

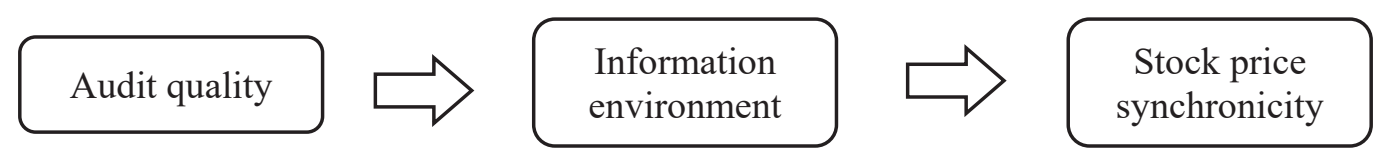

Figure 1: Hypothesis Illustration 
literature shows different results on the relationship between firm age and return synchronicity. Ntow-Gyamfi, Bokpin, and Gemegah(2015) documented that board independence is negatively correlated to synchronicity because, he argued, low synchronicity signifies the good information efficiency. On the contrary, Anh, Thu, and Quynh (2020) reported the opposite finding from the emerging market in Vietnam.

Firm size $(S I Z E)$ is defined as the company's total assets. While there exists the contrasting viewpoint on the relationship between stock synchronicity and the transparency of the information environment. Research seems to agree that stock price of larger firms capitalizes less firm-specific and more market-wide information, making it more synchronous to the market (Chan \& Chan, 2014; Piotroski \& Roulstone, 2004; Roll, 1988).

Foreign ownership $(F O W N)$ is the total proportion of firm shares held by international investors. In emerging markets, most of literature espouses the view that foreign investors help to improve the transparency of the market, and it confirmed that foreign ownership was significantly positive in predicting synchronicity (Anh, Thu, \& Quynh, 2020; Vo, 2017).

Ownership concentration $(L O W N)$ is the total proportion of firm shares held by shareholders holding from 5\% of the firm stocks. We add ownership concentration to this model as the typical variable for the Vietnamese market as firms in Vietnam are well characterized by highly concentrated ownership structure. This trait of ownership structure is also shared among emerging markets.

Risk $(R I S K)$ is the market volatility's proxy and measured by the standard deviation of the daily returns of the stock price (Equation (5)). The larger range of stock return standard deviation means the greater level of risk. Risk is estimated by the following formula:

$$
\operatorname{RISK}_{i, t}=\sqrt{\frac{1}{n} \sum_{j=1}^{n}\left(\text { Return }_{i, j}-\text { Mean }_{i, t}\right)^{2}}
$$

Leverage (LEV) is the firm's financial leverage. It is equal to the long-term debt divided by equity. This ratio is used as a control variable in some studies on stock price synchronicity (Boubaker, Mansali, \& Rjiba, 2014; Hutton, Marcus, \& Tehranian, 2009).

The market-to-book ratio $(M T B)$ is calculated as total debts' book value and equity's market value divided by total assets. Mixed results are found on the relationship between the market-to-book ratio and stockreturn synchronicity. Gul, Kim, and Qiu (2010) contended that a firm with a high market-to-book ratio has a lower level of stock return comovement to the market. The market-to-book ratio is often used as the proxy for the firm's value and growth opportunity. Higher market-to-book ratio may be the evidence of the firm's good abilities, signaling the efficiency and greater firm fundamentals incorporated in stock return and, thus, lower level of synchronicity. Nevertheless, the opposite outcome was shown in the studyby Ntow-Gyamfi, Bokpin, and Gemegah(2015).

\subsection{Data Collection}

Our data set includes listed firms on the Ho Chi MinhCity stock exchange (HOSE). Along with the Hanoi stock exchange (HNX), HOSE is one of the two administrative agencies of the SSC (State Securities Commission). After 20 years from the time of establishment, HOSE has grown rapidlywith more than 350 firms listed, thus, becoming the largest stock exchange in Vietnam. HOSE has stricter requirements for firms listed and is 16 times bigger than HNX in the total market capitalisation, which accounted for more than $70 \%$ of Vietnamese GDP in 2018. Therefore, although the number of companies listed in HOSE is only a small proportion of total firms in the economy, they are considered the largest firms with the best corporate governance mechanism.

Data for the research are provided by TaiViet Corporation, a leading financial data supplier in Vietnam. To be included in the research, firms must be non-financial companies, be listed, and remain listed in the period from 2014 to 2018.

\section{Results and Discussion}

\subsection{Descriptive Statistics}

Statistic results for all variables are shown in Table 1. Over 1115 valid observations, the value range of $\mathrm{R}$-square is from 0 to 0.93 . The mean of R-square is 0.095. Accordingly, the $\max$, min, and average figureof return synchronicity (SYNCH) are $-3,1.12$, and -1.43 , respectively. These figures are higher than in the past, the period from 2007 to 2015 , reported in the study of Vo (2017) with -17.8, 0.9, and -2.3, respectively. Therefore, it can be said that for this period, stock prices are more synchronous.

However, R-square and SYNCH of the Vietnamese market are relatively low, compared to the Chinese market, which revealed the average value of 0.43 and -0.23 and in the research of Gul, Kim, and Qiu (2010). A low level of R-square in an emerging market, as explained by Kelly (2014), might be a sign of a weak information environment.

The audit quality (AUDIT) is measured by the audit firm's size. It is the dummy variable receiving the value of 1 if the audit firm is big four and 0 otherwise. On average, 2 out of 10 firms in HOSE are audited by the Big Four.

Board independence (INDEP) is measured by the number of non-executive members on the board. It can be seen from Table 1 that Vietnamese firms have a max of 10 independent 
members on the board and there are listed companies with no independent members. This is under law enforcement because Vietnamese law for public companies requires at least one-third of the total number of members on the board to be independent.

For ownership concentration $(L O W N)$, it is noticeable that large shareholders in Vietnamese firms can hold up to more than $99 \%$ stocks of the companies. The majority of firm share held by the large owners is more likely to accompany with their extremely dominant voting rights and power in the companies. This is one of the typical features of firms in the Vietnamese emerging market, which can affect seriously to information reporting and disclosure process.

On average, foreign investors $(F O W N)$ own nearly $16 \%$ of the firm's shares. The maximum and minimum value is $78 \%$ and $0 \%$, respectively. These figures are higher than in the past as the Vietnamese government had removed the cap of foreign ownership in public firms from 2015, which was at $49 \%$. This policy aims to attract more foreign capital poured into the market, encouraging multiple ownership and creating motivations for economic development.

The correlation matrix is presented in Table 2. The only result that relates to the possibility of serious multicollinearity is the correlation between leverage (LEV) and market-to-book ratio (MTB), which has a value of 0.618 . However, after checking the VIF indexed shown in Table 3, we can conclude that there is no serious multi-colinearity problem in the model's variable set.

\subsection{Results and Discussion}

The outcomes of three models, including the pooled regression, the fixed effects, and the random effects model, are summarised in Table 3 . The F-test $=2.86$ with significance $\mathrm{P}<0.01$ indicates that the fixed effects model

Table 1: Descriptive Statistics

\begin{tabular}{|l|c|c|c|c|c|}
\hline & Obs. $^{* *}$ & Minimum & Maximum & Mean & Std. Deviation \\
\hline SYNCH & 1115 & -3.00 & 1.12 & -1.43 & 0.78 \\
\hline R-Square & 1115 & 0 & 0.930 & 0.095 & 0.108 \\
\hline AUDIT & 1115 & 0 & 1.00 & 0.19 & 0.69 \\
\hline INDEP & 1115 & 0 & 10.00 & 3.85 & 1.49 \\
\hline LOWN & 1115 & 0 & 99.51 & 49.79 & 22.49 \\
\hline FOWN & 1115 & 0 & 77.58 & 15.58 & 16.06 \\
\hline SIZE* & 1115 & 128,013 & $287,974,177$ & $4,544,700$ & $14,964,856$ \\
\hline RISK & 1115 & 103 & 52,852 & 3,606 & 4,856 \\
\hline LEV & 1115 & 0.01 & 140.26 & 1.68 & 4.83 \\
\hline MTB & 1115 & 0.07 & 35.44 & 1.25 & 1.42 \\
\hline
\end{tabular}

* SIZE unit: Million VND** Obs: Number of Observations

Table 2:Correlation Matrix

\begin{tabular}{|l|c|c|c|c|c|c|c|c|}
\hline & AUDIT & INDEP & LOWN & FOWN & SIZE & RISK & LEV & MTB \\
\hline AUDIT & 1 & & & & & & & \\
\hline INDEP & $.279^{* *}$ & 1 & & & & & & \\
\hline LOWN & 0.052 & 0.055 & 1 & & & & & \\
\hline FOWN & $.420^{* *}$ & $.198^{* *}$ & -0.001 & 1 & & & & \\
\hline SIZE & $.231^{* *}$ & $.249^{* *}$ & 0.021 & $.180^{* *}$ & 1 & & & \\
\hline RISK & $.170^{* *}$ & $.122^{* *}$ & $.125^{* *}$ & $.201^{* *}$ & $.151^{* *}$ & 1 & & \\
\hline LEV & -0.017 & $-.060^{*}$ & -0.036 & $-.082^{* *}$ & 0.017 & -0.036 & 1 & \\
\hline MTB & $.139^{* *}$ & $.092^{* *}$ & $.086^{* *}$ & $.075^{*}$ & $.147^{* *}$ & $.377^{* *}$ & $.618^{* *}$ & 1 \\
\hline Obs. & 1115 & 1115 & 1115 & 1115 & 1115 & 1115 & 1115 & 1115 \\
\hline
\end{tabular}

**. Correlation is significant at the 0.01 level (2-tailed).

*. Correlation is significant at the 0.05 level (2-tailed). 
is the more suitable in comparison to the regression model. The Hausman Test chooses the random effects model over the fixed effects model. Under the fixed effects model, the problem of heteroskedasticity is found and corrected byclustering (robust) the standard errors by the firm.

Under the random effects model, the coefficient of determination is 0.2615 , indicating that $26.25 \%$ of the variance in the stock synchronicity is predicted from the set of independent variables. Generally, audit quality (AUDIT), board independent (INDEP), foreign ownership $(F O W N)$, and firm size $(S I Z E)$ are found to be positively associated with stock return co-movement $(S Y N C H)$, while ownership concentration $(L O W N)$ and market-to-book $(M T B)$ show the negative impact on the return synchronicity.

The hypothesis proposed by the research is confirmed. The higher quality of the audit makes stock returns move more together. The better audit quality reduces information assymetry between managers and shareholders, between controlling shareholders and minority shareholders, and between firm outsiders and insiders. Auditors are viewed as information intermediators who assure the credibility of financial information reported. This result found in the context of the Vietnamese emerging market might imply that the information environment positively affects stock price synchronicity as well. Also, we found additional evidence supporting the latter view on the relationship between the quality of the information environment and the stock return's co-movement. Firstly, the regression outcome for other variables also reports the significantly impact of board independence and foreign ownership on synchronicity. It is wellestablished in the literature that the participation of non-executive directors on the company board or of international investors in the market as shareholders will help to enhance the transparency and efficiency of information environment at both firm-level and market-level. Therefore, it is reasonable that these two variables influence synchronicity in the same direction as the audit quality does. Secondly, the value of R-square produced from the modified Roll's model is at a relatively low level for the Vietnamese market. As interpreted by the recent trend in emerging markets, this can be referred as a poor informational environment.

\section{Conclusion}

This is a quantitative research, adopting the deductive approach to explain the causal relationship between audit quality and the stock co-movement's level in the market. We found that the quality of the audit is positively related to stock price synchronicity. This finding can be explained through the following mechanism: audit quality improves the transparency of the corporate reporting and disclosure, which in turn makes stock prices more synchronous. Hence, another implication of the finding might be the positive relationship between stock price synchronicity and the information environment. This suggestion adds more support to the recently dominant viewpoint on the behavior of stock synchronicity in ermerging markets.

However, we posited that this outcome does not negate the opposite standpoint suggested by prior research as stock prices function variously, following different direction in each particular market. In order to interpret an association,

Table 3:Regression Results

\begin{tabular}{|c|c|c|c|c|c|c|c|c|c|}
\hline & \multicolumn{2}{|c|}{ Pool OLS } & \multicolumn{2}{|c|}{ Fixed Effects } & \multicolumn{2}{|c|}{ Random Effects } & \multicolumn{2}{|c|}{ Robust REM } & \multirow[t]{2}{*}{ VIF } \\
\hline & Coef. & Std. Err. & Coef. & Std. Err. & Coef. & Std. Err. & Coef. & Std. Err. & \\
\hline AUDIT & $0.14^{* * *}$ & 0.047 & 0.067 & 0.108 & $0.106^{* *}$ & 0.059 & $0.106^{*}$ & 0.065 & 1.31 \\
\hline INDEP & $0.032^{* *}$ & 0.014 & 0.0410 & 0.108 & $0.038^{* *}$ & 0.017 & $0.038^{* *}$ & 0.018 & 1.15 \\
\hline FOWN & $0.020^{* * *}$ & 0.001 & $0.021^{* * *}$ & 0.003 & $0.020^{* * *}$ & 0.002 & $0.020^{* * *}$ & 0.002 & 1.28 \\
\hline LOWN & $-0.005^{* * *}$ & 0.001 & -0.002 & 0.002 & $-0.005^{* * *}$ & 0.001 & $-0.005^{\star * *}$ & 0.001 & 1.03 \\
\hline SIZE & $5.8 \mathrm{E}-09^{* * *}$ & 1.4E-09 & $-5.7 E-09$ & 3.5E-09 & $4.0 \mathrm{E}-09^{* *}$ & 1.8E-09 & $4.0 \mathrm{E}-09^{* *}$ & 1.9E-09 & 1.13 \\
\hline RISK & $-6.8 E-06$ & 4.8E-06 & $-3.1 E-06$ & 6.1E-06 & $-6.2 E-06$ & 5.1E-06 & $-6.2 E-06$ & 4.4E-06 & 1.38 \\
\hline LEV & 0.018 & 0.006 & $0.019^{*}$ & 0.010 & 0.018 & 0.007 & 0.018 & 0.006 & 1.99 \\
\hline MTB & $-0.062^{* * *}$ & 0.021 & $-0.073^{* *}$ & 0.035 & $-0.064^{* * *}$ & 0.024 & $-0.064^{* * *}$ & 0.024 & 2.32 \\
\hline \multicolumn{3}{|c|}{ R-Square } & \multicolumn{2}{|c|}{0.2751} & \multicolumn{2}{|c|}{0.2615} & & & \\
\hline \multicolumn{3}{|l|}{ F-test } & \multicolumn{2}{|c|}{$2.86^{* * *}$} & & & & & \\
\hline \multicolumn{3}{|c|}{ Hausman Test } & \multicolumn{2}{|c|}{6.74} & & & & & \\
\hline \multicolumn{3}{|c|}{ Chi-square (x2) Heteroskedasticity) } & \multicolumn{2}{|c|}{$157.39 * * *$} & & & & & \\
\hline \multicolumn{3}{|c|}{ Observations } & \multicolumn{2}{|c|}{1115} & & & & & \\
\hline
\end{tabular}


we first need to put it in a particular context and learn about the nature of that environment.

\section{References}

Almarayeh, T., Aibar-Guzmán, B., \& Abdullatif, M. (2020). Does audit quality influence earningsmanagement in emerging markets? Evidence from Jordan. Revista De Contabilidad, 23(1), 64-74.https://doi.org/10.6018/rcsar.365091

Anh,N., Thu,V.,\& Quynh,D.(2020). Corporate Governance and Stock Price Synchronicity: Empirical Evidence from Vietnam. International Journal of Financial Studies,8(2), 1-13.https:// doi.org/10.3390/ijfs8020022

Bertrand, M., Mehta, P., \& Mullainathan, S. (2002). Ferreting Out Tunneling: An Application to Indian Business Groups. The Quarterly Journal of Economics, 117(1), 121-148. https://doi. org/10.1162/003355302753399463

Boubaker, S., Mansali, H., \& Rjiba, H. (2014). Large controlling shareholders and stock price synchronicity. Journal of Banking and Finance, 40(1), 80-96.https://doi.org/10.1016/j. jbankfin.2013.11.022

Chae, S. J., Nakano, M., \& Fujitani, R. (2020). Financial reporting opacity, audit quality and crash risk: Evidence from Japan. Journal of Asian Finance, Economics and Business, 7(1), 9-17. https://doi.org/10.13106/jafeb.2020.vol7.no1.9

Chan, K.,\& Chan, Y.C. (2014). Price informativeness and stock return synchronicity: Evidence from the pricing of seasoned equity offerings. Journal of Financial Economics, 114(1), 3653. https://doi.org/10.1016/j.jfineco.2014.07.002

Chan, K.,\& Hameed, A. (2006). Stock price synchronicity and analyst coverage in emerging markets. Journal of Financial Economics,80(1), 115-147. https://doi.org/10.1016/j. jifineco.2005.03.010

Chen, K. C., \& Yuan, H. (2004). Earnings management and capital resource allocation: Evidence from China's accounting-based regulation of rights issues. Accounting Review, 79(3), 645-665. https://doi.org/10.2308/accr.2004.79.3.645

Cohen, D., Dey, A., \& Lys, T. (2008). Real and accrual-based earnings management in the pre and post-Sarbanes- Oxley periods. The Accounting Review, 83(3), 757-787. https://doi. org/10.2308/accr.2008.83.3.757

Dasgupta, S., Gan, J., \& Gao, N. (2010). Transparency, Price Informativeness, and Stock Return Synchronicity: Theory and Evidence. Journal of Financial and Quantitative Analysis, 45(5), 1189-1220.https://doi.org/10.1017/S0022109010000505

DeAngelo, L. (1981). Auditor size and audit quality.Journal of Accounting and Economics, 3(3),183-199.https://doi. org/10.1016/0165-4101(81)90002-1

Farooq, O., \&Ahmed, S. (2014). Stock Price Synchronicity and Corporate Governance Mechanisms: Evidence from an Emerging Market. International Journal of Accounting, Auditing and Performance Evaluation, 10(4), 395-409. https:// doi.org/10.1504/IJAAPE.2014.066392
Fernandes, N., and Ferreira M. (2009). Insider Trading Laws and Stock Price Informativeness. The Review of Financial Studies, 22(5), 1845-887. https://doi.org/10.1093/rfs/hhn066

Gul, F., Kim, J., \& Qiu, A. (2010). Ownership concentration, foreign shareholding, audit quality, and stock price synchronicity: Evidence from China. Journal of Financial Economics, 95(3), 425-442.https://doi.org/10.1016/j. jfineco.2009.11.005

Haggard, K., Martin, X., \& Pereira, R. (2008). Does Voluntary Disclosure Improve Stock Price Informativeness? Financial Management, 37(4), 747-768.https://doi.org/10.1111/j.1755053X.2008.00033.X

Hu, C., \&Liu, S.(2013). The Implications of Low R2: Evidence from China. Emerging Markets Finance and Trade,49(1), 1732. https://doi.org/10.2753/REE1540-496X490102

Hussainey, K. (2009). The impact of audit quality on earnings predictability. Managerial Auditing Journal, 24(4), 340-351. https://doi.org/10.1108/02686900910948189

Hutton, A.P., Marcus, A.J., Tehranian, H. (2009). Opaque financial reports, R2, and crash risk. Journal of Financial Economics, 94, 67-86. [https://doi.org/10.1016/j.jfineco.2008.10.003

Jin, L., and Myers, S. (2006). R2 Around the World: New Theory and New Tests. Journal of Financial Economics, 79, 257-292. https://doi.org/10.1016/j.jfineco.2004.11.003

Kelly, P. (2014). Information efficiency and firm-specific return variation.Quarterly Journal of Finance, 4, 1450018. https://doi. org/10.1142/S2010139214500189

Kim, J.B., Chung, R.,\& Firth, M. (2003). Auditor conservatism, asymmetric monitoring and earnings management. Contemporary Accounting Research, 20, 325-359. https://doi. org/10.1506/J29K-MRUA-0APP-YJ6V

Legoria, J., Reichelt, K.J., \& Soileau, J.S. (2017). Auditors and disclosure quality: The case of major customerdisclosures. Auditing: A Journal of Practice \& Theory, 37(3), 163-189. https://doi.org/10.2308/ajpt-51835

Mansi, S.A., Maxwell, W.F. and Miller, D.P. (2004). Does auditor quality and tenure matter to investors? Evidence from the bondmarket.Journal of Accounting Research, 42(4), 755-793. https://doi.org/10.1111/j.1475-679X.2004.00156.x

Morck, R., Yeung, B., \& Yu, W. (2000). The information content of stock markets: Why do emerging markets have synchronous stock price movements?.Journal of Financial Economics, 58(1), 215-260.https://doi.org/10.1016/S0304-405X(00)00071-4

Ntow-Gyamfi, M., Bokpin, G., \& Gemegah, A. (2015). Corporate governance and transparency: Evidence from stock return synchronicity. Journal of Financial Economic Policy, 7(2), 157-179.https://doi.org/10.1108/JFEP-10-2013-0055

Piotroski, J., \& Roulstone, D. (2004). The Influence of Analysts, Institutional Investors, and Insiders on the Incorporation of Market, Industry, and Firm-Specific Information into Stock Prices. The Accounting Review, 79(4), 1119-1151. https://doi. org/10.2308/accr.2004.79.4.1119 
Rahman, M. M., Meah, M. R., \& Chaudhory, N. U. (2019). The Impact of Audit Characteristics on Firm Performance: An Empirical Study from an Emerging Economy. Journal of Asian Finance, Economics and Business, 6(1), 59-69.http://doi. org/10.13106/jafeb.2019.vol6.no1.59

Roll, R. (1988). R2. Journal of Finance,43, 541-566. https://doi. org/10.1111/j.1540-6261.1988.tb04591.x

Salehi, M., Moradi, M., \& Paiydarmanesh, N. (2017). The effect of corporate governance and audit quality ondisclosure quality: Evidence from Tehran Stock Exchange. Periodica Polytechnica
Social and Management Sciences, 25(1), 32-48. https://doi. org/10.3311/PPso.8354

Vo, X. (2017). Do foreign investors improve stock price informativeness in emerging equity markets? Evidence from Vietnam. Research in International Business and Finance,42, 986-991. https://doi.org/10.1016/j.ribaf.2017.07.032

Wachid, F., \& Yunita, D. (2019). The disclosure of financial and non-financial performance via narrative communication: Islamic Bank Annual Report. Sebelas Maret Business Review, 4(2), 77-92. https://doi.org/10.20961/smbr.v4i2.36042 